\title{
TINJAUAN KOGNISI SOSIAL TERHADAP SOSIAL BUDAYA
}

\author{
Tenny Sudjatnika
}

\begin{abstract}
Abstrak
Hasil prilaku manusia sering dipengaruhi oleh orang lain dan kondisi stimulus dengan mekanisme dari proses pembiasaan merespon dan peniruan model. Teori ini arahnya pada peran sosial model manusia pada motivasi, pikiran dan tindakan berdasarkan pembelajaran observasional sebagai hasil determinasi resiprokal antara kognitif, prilaku dan lingkungan. Prosedur belajar sosial diatas sama halnya dengan prosedur belajar dalam presfektif Studi Islam. Hanya saja dalam presfektif Islam, dipengaruhi oleh bawaan (fitrah) yang dilakukan melalui belajar keteladanan Islami, belajar nilai (keyakinan, kebajikan, kebenaran dan kesabaran), belajar pola asuh (koersif, permisif dan dialogis melalui bahasa petunjuk, bahasa keterampilan, bahasa ilmiah dan bahasa lifeskills), belajar nalar dan belajar naturalis. Segala sesuatu yang diindrakannya akan mempengaruhi pembentukan mental. Sementara itu di masyarakat religius Islam, religi berfungsi sebagai etos dan motivasi, sebab di dalamnya mempengaruhi potensi fitrah yang dipertimbangkan secara kognisi berdasarkan pertimbangan daya akal, daya kalbu dan daya nafsu sehingga menghasilkan asy-syakhshiyat (kepribadian) yang terkategori pada kepribadian yang mendapat hidayah dan kepribadian yang tidak mendapat hidayah. Islam dengan landasan ajaran spiritual, etika dan moral yang khas atas kewahyuan dan suri tauladan yang sami'na wa atha'na harus menjadi penyeimbang, penserasi, penyelaras antara dunia dan akhirat dan menjadi inspirasi dan stimulus nilai-nilia moral yang berperadaban. Oleh karena itu, umat Islam dengan penuh kejujuran harus mampu bekerja keras meningkatkan civilitasi ilmu pengetahuan yang bermutu pendidikan, penguasaan teknologi yang aksiologis berfondasi kepribadian yang mantap, cerdas, berkualitas berdasarkan Islam. Ekspresinya ijtihad menjadi dinamika peradaban Islam yang penting dalam memecahkan persoalan sosial budaya masa kini dan ke depan.
\end{abstract}

\section{A. Pendahuluan}

Teori kognisi sosial diawali dari teori tentang belajar observasional. Ia memandang tingkah laku manusia diakibatkan atas reaksi yang timbul dari interaksi antara lingkungan dengan skema kognitif manusia itu sendiri dengan prinsip dasar temuannya bahwa belajar adalah termasuk dasar belajar sosial dan moral. Tekanan dasarnya adalah hasil prilaku bergantung pada pengaruh orang lain dan kondisi stimulus dengan mekanisme perolehan moralnya adalah hasil dari proses conditioning (pembiasaan merespons) dan proses imitation (peniruan) dari modeling (figur/tokoh) sebagai contoh berprilaku sosial dan moral. (Muhibin Syah, 1995: 74).

Sehubungan dengan hal itu dalam Studi Islam, ada beberapa kaidah-kaidah sosial dan moral yang 
ditekankan atas dasar pembawaan (fitrah) yang mencakup beberpa potensi seperti beragama, intelek, sosial, ekonom, seni, kemajuan, keadilan, kemerdekaan, keturunan, cinta dan sebagainya. (Muhaimin \& Mujib, 1993: 25). Potensi-potensi tersebut mendapatkan pengaruh lingkungan dalam mengembangkan dan melestarikan potensi positifnya atau kepribadiannya sehingga dapat senantiasa hidup lurus dengan tujuan yang menciptakannya.

Dalam perkembangannya, fitrah dapat dimodifikasi atau diubah baik secara positif maupun negatif. Apabila lingkungan itu tidak memungkinkan untuk menjadikan fitrah lebih baik, maka akan cenderung menjadi tidak terkendali. Sebaliknya, apabila lingkungan itu memungkikan menjadikan fitrah lebih baik, maka fitrah akan terarah dan terkendali. Faktor-faktor eksternal yang bergabung dengan fitrah dan sifat dasarnya bergantung pada peran interaksi eksternal dengan fitrah itu. Sebaliknya, menurut pengamat behavioris, fitrah tidak mengharuskan manusia untuk berusaha keras terhadap lingkungannya. (Ibid: 26-27). Penyimpangan fitrah merupakan akibat dari faktor pendidikan (Ahmad, tt: 31). Dalam hal ini pendidikan termasuk di dalamnya adalah mengenai belajar sosial dan moral. Jika itu terjadi akan berdampak pada sosial budaya.

Dari uraian di atas, maka muncul pertanyaan: bagaimana tinjauan kognisi sosial perspektif Islam relevansinya terhadap kinerja individu dan implikasinya terhadap Sosial Budaya?

\section{B. Pembahasan}

$\begin{array}{ccc}\text { Sosial } & \text { Learning } & \text { Teory } \\ \text { berawal dari } & \text { pengaruh } & \text { paham }\end{array}$

epistemologi tentang pengetahuan, bahwa satu sisi pengetahuan adalah diwariskan, oleh karenanya merupakan komponen natural dari pikiran manusia. Sisi lain pengetahuan berasal dari pengalaman indrawi dan tidak diwariskan. Namun bisa jadi pikiran dan perenungan bisa terlibat aktif dalam mengungkap perolehan pengetahuan.

Kedua pandangan tersebut melahirkan tiga padangan epistemologi; rasionalis, nativis dan empiris. Dari ketiga aliran itu dalam psikologi melahirkan madzhab psikologi awal: voluntarisme, strukturalisme, fungsionalisme dan behaviorisme. Pada madzhab behaviorisme menekankan pada metode eksperimental yang fokus pada variable yang diukur, diamati dan menghindari subjektivitas, internal dan sifat mentalitas, yaitu dengan menggunakan prosedur standard dan mengukur pengaruhnya terhadap yang lain, sehingga berakhir pada teori kepribadian bahwa lingkungan penyebab perilaku salah (Boeree,

http://webspace.ship.edu/cgboer/ban dura.htmlAlbertBandura.[17 April 2010)

Pandangan teori behaviorisme, bahwa prilaku harus dijelaskan melalui pengalaman yang diobservasi bukan dengan proses mental. Perilaku adalah segala sesuatu yang dilakukan dan bisa dilihat secara langsung. Sementara oleh para psikolog, mental didefinisikan sebagai suatu pikiran, perasaan dan motif yang tidak bisa dilihat oleh orang lain (Santrock, alih bahasa Tri Wibowo B.S, 2008: 266).

Watson dan Thorndike mengganggap bahwa belajar hanya berasal dari direct experience (pengalaman langsung). Mereka 
berpendapat bahwa belajar terjadi sebagai hasil dari interaksi dengan lingkungan, bukan dari hasil pengamatan. Hal ini menimbulkan empat pendekatan teori psikologi: fungsionalistik domain, teori assosiasonistik domain, teori kognitif domain dan teori neurofisiologis domain.

Pada teori kognitif domain melahirkan teori-teori baru yang fokus pada pendekatan untuk pembelajaran. Salah satunya adalah teori belajar sosial. Teori ini didasarkan atas bagaimana manusia memperhatikan perilaku model yang menjadi penguat di lingkungan. Dalam eksperimennya, mereka melihat bahwa prilaku manusia dikendalikan oleh motivasi dan respons organisme yang dapat menstimulasi organisme lain, yaitu generalized imitation, dan imitasi ini dapat menjadi kebiasaan (Hergenhahn \& Olson, alih bahasa oleh Tri Wibowo B.S, 2008: 358359).

Kemudian Alber Bandura, melanjutkan penelitian atas dasar pandangan bahwa lingkungan yang menyebabkan prilaku, tetapi prilaku juga menyebabkan prilaku lingkungan. Dunia dan perilaku penyebab satu sama lain (Boeree, tersedia:

http://webspace.ship.edu/cgboer/ban dura.htmlAlbertBandura, 17 April 2010). Bandura menamakan teorinya sebagai teori kognitif sosial (Social Cognitif Theory).

Sejumlah besar variasi pada penelitian teori ini diawali arahannya pada peran sosial model manusia pada motivasi, pikiran dan tindakan (Wikipedia, tersedia: $\mathrm{h} t t p / / w w w . e m o r y . e d u / E D U C A T I O N /$ mfp/bandurabio.html). Salah satu hasil studi, pertama bahwa pembelajaran observasional terjadi sama eksistensinya baik ketika prilaku agresi diperkuat maupun tidak diperkuat. Kedua, studi ini fokus pada perbedaan antara pembelajaran dan kinerja. Orang tidak melakukan respons bukan berarti mereka tidak mempelajarinya, melainkan saat mereka diberi insentif untuk meniru model, perbedaan dalam prilaku imitatif hilang. Ketika mereka mengamati prilaku tetapi tidak memberikan respons yang dapat diamati, mungkin masih mendapatkan respons model dalam bentuk kognitif (Ibid). Dari semua variasi studinya di atas ditetapkan bahwa faktor lingkungan, faktor kognitif dan faktor prilaku semuanya berinteraksi untuk menghasilkan prilaku selanjutnya (Bandura, 1986): 24).

Prilaku manusia sebagian besar adalah pertama, Self-regulated behavior (prilaku yang diatur sendiri). Diantara hal-hal yang dipelajari manusia dari pengalaman langsung atau tidak langsung adalah performance standards (standar tontonan). Setelah standar tontonan dipelajari standar itu menjadi basis bagi evaluasi diri. Jika tontonan atau tindakan dalam situasi tertentu memenuhi atau melebihi standar, maka akan dinilai positif, sebaliknya jika tidak, akan dinilai negatif. Prilaku yang dihargai oleh dirinya sendiri cenderung dipertahankan lebih efektif ketimbang jika prilaku itu diperkuat secara eksternal (Bandura, 1976: 144). Tetapi standar tontonan yang keras untuk evaluasi diri akan menimbulkan reaksi depresi, kelesuan kronis, perasaan tidak berguna, dan kurang arah tujuan (Ibid: 141 dan Bandura, 1980: 31). 
Kedua, Perceived self-
efficacy (anggapan tentang kecakapan diri) yaitu keyakinann seseorang tentang kemampuanya dalam melakukan sesuatu dan muncul dari berbagai macam sumber. Sumber tersebut bisa dari prestasi, kegagalan personal yang pernah dialami, melihat orang-orang yang sukses atau gagal, dan persuasi verbal (Hergenhahn \& Olson, 2008: 370-371). Orang dengan anggapan kecakapan diri yang tinggi cenderung lebih, punya kendali atas kejadian dalam lingkungan sehingga mereka merasa lebih pasti. Sebaliknya individu yang cenderung takut terhadap kejadian yang tidak bisa mereka kontrol akan merasa bersifat tidak pasti. Oleh karena itu, individu yang memiliki anggapan kecakapan diri yang tinggi akan cenderung kurang merasa takut (Bandura, 1976: 144). Anggapan kecakapan diri seseorang bisa berhubungan atau tidak berhubungan dengan real selfefficacy (kecakapan diri yang sesungguhnya). Orang mungkin percaya bahwa kecakapan diri mereka rendah padahal sebenarnya cukup tinggi dan sebaliknya. Situasi terbaik adalah ketika anggapan seseorang itu sesuai dengan kemampuan sesungguhnya. Di satu sisi orang senantiasa berusaha untuk melakukan sesuatu di luar kemampuannya. Hal ini akan mengalami frustasi dan putus asa dan bahkan akan selalu gampang menyerah. Di sisi lain, jika orang memilki anggapan kecakapan diri yang tinggi tidak menghadapi tantangan yang memadai, perkembangan personalnya mungkin terlambat (Hergenhahn \& Olson, 1980: 371). Keyakinan tentang kecakapan tidak hanya memprediksi fungsi behavioral antar individu pada tingkat anggapan kecakapan diri yang berbeda, tetapi juga memprediksi perubahan dalam fungsi individu pada tingkat kecakapan diri yang berbeda dari waktu ke waktu, bahkan memperbaiki variasi di dalam individu yang mempunyai kecakapan sama dalam menjalankan tugas baik yang sukses atau gagal (Bandura \& Locke, tt: 87-88).

Ketiga, moral code (kode moral) yang berkembang melalui interaksi dengan model. Biasanya orang memberi contoh aturan moral yang kemudian diinternalisasi oleh orang lain. Setelah itu kode moral akan menentukan prilaku atau pikiran mana yang akan mendapatkan hukuman dan mana yang tidak? Apabila terjadi penyimpangan kode moral kemungkinan akan terjadi sikap selfcontemp (mencela diri atau penyeselan) karena terbiasa melakukan sesuai dengan kode moral. Rasa mencela diri atau penyesalan setelah melanggar standar akan menjadi sumber motivasi bagi seseorang untuk menjaga prilakunya sejalan dengan standarnya saat berhadapan dengan motif yang bertentangan. Tidak ada hukuman yang lebih buruk ketimbang pencelaan diri (Bandura, 1986: 154).

Determinisme resiprokal (umpan balik positif) ketiga faktor di atas semuanya berinteraksi untuk menghasilkan prilaku selanjutnya. Istilah yang digunakan dalam arti tindakan umpan balik antara peristiwa tersebut, bukan dalam arti sempit tindakan yang sama atau berlawanan, tetapi merupakan gabungan dari kedua faktor penentu pribadi dan lingkungan yang menggambarkan prilaku sebagai 
hasil dari pengaruh gabungan dari kedua factor (lingkungan dan person).

Istilah person dideskripsikan pada faktor kognitif yang mencakup ekspektasi, keyakinan, strategi, pemikiran dan kecerdasan (Santrock, tt: 266). Faktor person adalah self efficacy yaitu keyakinan seseorang bahwa ia bisa menguasai situasi dan menghasilkan hasil yang positif. Self efficacy berpengaruh besar terhadap prilaku. Misalnya, seorang yang self efficacy-nya rendah mungkin tidak mau berusaha untuk mengerjakan pekerjaan karena tidak percaya bahwa ia akan bisa berkelanjutan saling mempengaruhi antara pribadi, prilaku, dan lingkungan.

Saling ketergantungan pribadi dan pengaruh lingkungan terjadi karena pengaruh yang diberikan oleh individu dan oleh tingkah lakunya ditunjuk bersama sebagai determinan pribadi. Seperti faktor pribadi internal dan perilaku juga operan sebagai penentu umpan balik satu sama lain. Contoh, harapan masyarakat mempengaruhi cara mereka berprilaku, dan hasil dari prilaku mereka mengubah ekspektasi mereka. Keduanya menentukan operasi yang berbeda. Sebagian besar lingkungan merupakan potensi untuk mewujudkan tindakan yang sesuai. Dosen tidak mempengaruhi mahasiswa kecuali mereka dipilih dan membacanya. Api tidak membakar orang kecuali mereka menyentuh api. Manfaat menghukum berpengaruh terhadap penundaan, tetapi tetap diaktifkan dengan kinerja bersyarat. Demikian pula determinan pribadi, yang berpengaruh hanyalah potensi-potensi yang tidak operan kecuali bila mereka diaktifkan. Jika mereka berbicara, maka orang-orang yang dapat berbicara sok tahu tentang isu-isu tertentu untuk mempengaruhi orang lain, tetapi tidak berpengaruh jika mereka diam, meskipun mereka memiliki sarana untuk melakukannya (Bandura, 1976: 195).

Belajar sosial merujuk pada fakta bahwa kita membutuhan begitu banyak prilaku dengan mengobservasi dan meniru orang lain dalam konteks sosial. Fungsi kognitif tidak bisa diabaikan dalam menjalankan, memahami dan memodifikasi prilaku individual (Gibson, Ivancevich, Donnelly, alih bahasa Nunuk Adiarni, 1996: 223224).

\section{Hipotesis}

Belajar sosial pada dasarnya adalah belajar memahami masalahmasalah dan tehnik-tehnik untuk memecahkan masalah sosial seperti masalah keluarga, masalah persahabatan, masalah kelompok dan masalah-masalah lain yang bersifat kemasyarakat. Berguna untuk mengatur dorongan nafsu pribadi demi kepentingan bersama dam memberi peluang kepada orang lain atau kelompok untuk memenuhi kebutuhannya secara berimbang dan proporsional (Muhibbin Syah, 2009: 120-121).

Super ego pribadi manusia yang terdiri atas hati nurani, normanorma, cita-cita pribadi terbentuk dan berkembang melalui pergaulan sosial atau dikenal dengan interaksi sosial (Gerungan, 2004: 27). Interaksi sosial muncul karena adanya ketertarikan. Ketertarikan muncul karena adanya kesamaan sikap dan nilai (Ahmadi, 2007: 211). Melalui itulah manusia dapat melakukan autoplastis dengan memahami berbagai faktor dan kondisi yang dapat membentuk 
prilaku dan pemikiran sosialnya berupa tingkah laku, perasaan, keyakinan, ingatan dan penyimpulan mereka tentang diri dan orang lain (Baron, 2004: 9). Dengan kata lain, manusia berinterkasi dalam membentuk prilakunya dipengaruhi oleh proses kognitif, variabelvariabel lingkungan, konteks budaya dan faktor biologis (Ibid: 10-12).

Reaksinya terhadap orang lain sangat dipengaruhi oleh penampilan luar orang lain. Proses pembentukan prilakunya dipelajari melalui respons penyaksian cara dan fitur orang atau sekelompok orang dalam sebuah stimulus tertentu. Respons tersebut diperkuat dengan respons baru dengan cara pengamatan terhadap prilaku contoh dari orang lain, misalnya orangtua, dosen, guru atau pimpinan. Selanjutnya dilakukan dengan peniruan dan pembiasaan (Muhibin Syah, 2009: 107). Perolehan dari pengamatan atas pengalamannya merupakan suatu rangkaian anthropological constants yang saling berpengaruh.

Prosedur belajar sosial dalam perspektif studi Islam dipengaruhi oleh eksternal, internal dan personality. Luar dirinya dapat berupa lingkungan (bi'ah/milieu), dalam dirinya berupa fisik dan psikis (fitrah), al-syakhshiyat/personality dapat berupa kesan yang ditimbulkan individu terhadap orang lain sebagai hasil pengaturan individu pada sistem fisik dan psikis berupa kebiasaan prilaku.

$\begin{array}{lrrr} & \text { Jenis-jenis } & \text { Belajar } & \text { Sosial } \\ \text { dalam } & \text { Persfektif } & \text { Studi } & \text { Islam }\end{array}$
diklasifikasikan pada (1) Belajar Keteladan Islami yaitu belajar untuk menjadi model yang terbaik bagi masyarakat, lingkungan, agama, bangsa dan negara dengan berlandaskan keimanan. (2) Belajar Nilai yaitu belajar untuk meyakini keyakinannya (keimanan), kebajikan, kebenaran dan kesabaran yang akan menentukan integritas, komitmen, eksistensi dan konsistensi dalam perjalanan sejarah hidup dan kehidupan. (3) Belajar Pola Asuh yaitu belajar membuat model pemikiran dan prilaku yang dapat menciptakan lingkungan yang kondusif dan positif. (4) Belajar Nalar yaitu belajar untuk mempertimbangkan tentang baik dan buruk yang memungkinkan untuk berfikir logis (sesuai dengan akal). (5) Belajar Naturalis yaitu belajar menyesuaikan dalam memposisikan dirinya di suatu tempat atau lingkungan. Contoh di lingkungan keluarga, sekolah, masyarakat, teman, komunitas dan sebagainya; di alam tertutup, terbuka, panas, dingin, tropis, salju dan sebagainya (Ibid).

Ada tiga jenis belajar pola asuh: (1) Koersif yaitu belajar sosial yang menggunakan sistem paksaan dan kekerasan, hasilnya akan menjadi tertib tetapi tidak bebas; (2) Permisif yaitu belajar sosial yang bersifat terbuka, membiarkan, selalu mengijinkan, mempersilahkan, hasilnya akan menjadi bebas tetapi tidak tertib; (3) Dialogis yaitu belajar sosial yang bersifat terbuka dan komunikatif, hasilnya menjadi bebas tetapi tertib. Jenis pola asuh dialogis ini salah satunya adalah belajar bahasa yaitu belajar mendengarkan dan verbalisasi dalam berbagai bentuk untuk mengekspresikan pemikiran, dan prilaku (Syarifuddin, 1995: 52).

Ada beberapa jenis bahasa yang dapat digunakan: (1) bahasa petunjuk yaitu bahasa agama; (2) bahasa keterampilan yaitu praktik kemampuan membaca, menulis, 
menyususn kata-kata, berbicara; (3) bahasa ilmiah yaitu bahasa ilmu pengetahuan; (4) bahasa lifeskills yaitu bahasa menghadapi kehidupan (Ibid).

Pada dasarnya cara belajar sosial di atas sama halnya dengan cara belajar sosial dalam perspektif pendidikan Islam. Segala sesuatu yang diindrakannya akan mempengaruhi pembentukan mental. Mental dibentuk oleh segala sesuatu yang datang dari pengalamannya melalui pengindraan sejak lahir sampai meninggal (Ibid). Namun Insting meniru akan lebih kuat ketika masa kanak-kanak. Oleh karena itu metode yang paling tepat dalam sosial learning adalah uswatun hasanah (metode teladan) melalui perkataan, perbuatan, sikap dan tingkah laku.

Salah satu pemberian contoh yang paling penting dalam pembentukan mental adalah dalam hal keagamaan. Hal ini menurut Syarifuddin dikarenakan agama memiliki beberapa faktor, antara lain: Faktor kreatif yang mendorong dan merangsang untuk melakukan kerja produktif, faktor inovatif yang melandasi cita-cita dan amal perbuatan dalam seluruh aspek kehidupan, faktor sublimasi yang dapat meningkatkan dan mengkuduskan dalam segala kegiatan yang bersifat keagamaan. Faktor integratif yang mempersatukan pandangan dan sikap serta memadukan berbagai kegiatan baik pribadi maupun kemasyarakatan dalam berbagai penghayatan agama guna menghindari perpecahan sehingga mampu menghadapi tantangan hidup.

Deteminasi belajar sosial dalam persfektif Islam: Pertama, Orang (Person), penekanannya dihadapkan pada signifikasi fungsi fitrah an-nafsaniyah antara fungsi kognitif (qawwah al-aql) dengan fungsi pancaindera (thaqhat aljismiyah) yang dipengaruhi oleh qawwah al-qalb dan qawwah an-nafs (nafsu) yang menghasilkan assyakhsyiyah sehingga menghasilkan kemungkinan diantara kepribadian yang didasari taufik dan kepribadian yang didasari oleh syakhwat.

Dalam teori kognitif sosial (social learning) tidak mengenal adanya konsep bawaan, sementara dalam perspektif studi Islam, manusia dibekali dengan fitrah yang merupakan sifat bawaan manusia yang dibawa sejak lahir. Hal ini yang membedakan konsep kognitif psikologi sosial dengan kognisi perspektif studi Islam. Sehingga dalam perspektif studi Islam pada taraf proses motivasional masih dapat diupayakan melalui pengetahuan agama.

Selanjutnya lingkungan yang meliputi individu-individu dapat memberi pengaruh atau dipengaruhi sehingga menuntut keharusan bergaul. Dari sebuah pergaulan terjadi penyesuaian diri baik secara alloplastis maupun autoplasstis, sehingga membentuk suatu komunitas. Komunitas dalam pandangan Islam disebut kaum yang seakar dengan bangsa dan sepadan dengan ummat. Dalam pandangan Islam, masa depan ummat divisualisasikan melalui keberadaan mental (batin) dan struktur masyarakat yang kuat. Kedua visualisasi ini menunjuk pada aspek intelektual yang mendorong dan mencakup tujuan (Hidayat, 2003: 58). Hal ini dijelaskan dalam alQur'an surah Ar-Ra'd [13] ayat 11.

Di dalam hadits ada beberapa bukti tekstual pengaruh lingkungan 
terhadap seseorang. Hadist ini berbunyi :

"Tiap bayi lahir dalam keadaan fitrah (suci membawa disposisi Islam). Orang tuanyalah yang membuat ia Yahudi, Nasrani, atau Majusi. Seperti binatang yang lahir sempurna, adakah engkau melihat mereka terluka pada saat lahir?" (H.R. Bukhari)

Hadist lain menunjukkan bahwa teman dapat mempengaruhi prilaku, karakter, dan perbuatan seseorang dengan memberikan perumpamaan. Nabi Muhammad SAW bersabda :

"Persamaan teman yang baik dan buruk dan yang buruk seperti pedagang minyak kesturi dan penipu api tukang besi. Si pedagang minyak kesturi mungkin akan memberinya padamu atau engkau akan membeli kepadanya, atau setidaknya engkau dapat memperoleh bau yang harum darinya. Tapi si penipu api tukang besi mungkin akan membuat pakaianmu terbakar atau kamu akan mendapatkan bau yang tidak sedap dari padanya." (H.R. Bukhori)

Hal ini mengingatkan bahwa persahabatan yang baik dapat mempengaruhi karakter seseorang menjadi baik dan teman yang jahat dapat membuat orang melakukan hal yang buruk. Dengan demikian, lingkungan dapat mempengaruhi keseluruhan perkembangan psikologi seseorang termasuk tentunya perkembangan kognitif. Sofwan Anwar Mufid mengatakan bahwa komunitas Islam terbentuk dari prinsip keteladaanan Rasulallah SAW. Keteladanan Rasulallah baik secara konseptual maupun tehnis oprasional memberi komitmen dan integritas ummat dalam setiap aktivitas yang dicontohkan (Mufid, 2010: 276). Secara umum prinsip keteladan tersebut membentuk komunitas lingkungan religius.

Lingkungan dalam perspektif Islam meliputi kedalam dua jenis. Pertama, lingkungan madiyah (fisik) seperti iklim, tempat tinggal, pakaian dan makanan. Kedua, lingkungan maknawiyah (non-fisik) seperti lingkungan pendidikan, budaya, sosial dan religius. Lingkungan Islami adalah suatu lingkungan yang didalamnya terdapat ciri-ciri keislaman, yang memungkinkan terselenggaranya pendidikan Islam dengan baik.

Nurwajah

Ahmad menjelaskan bahwa dalam Al Qur'an tidak menjelaskan lingkungan secara tersurat, tetapi secara tersirat menyebutkan tiga jenis lingkungan yang mempengaruhi sikap seseorang. Jenis lingkungan itu adalah lingkungan alamiah, lingkungan sosial kultural dan lingkungan religious (Ahmad, 2007: 128-129). Lingkungan alamiah terbentuk dengan sendirinya karena adanya kebutuhan manusia dalam sebuah ekosistem manusia dalam berinteraksi dengan lingkungan sekitar, seperti tempat tinggal, tempat belajar, tempat bergaul dengan suasan yang panas, dingin, atau sejuk, bising, sunyi atau kondusif.

Lingkungan sosial kultural terjadi atas dasar norma, susila dan prinsip sosial dalam keluarga atau masyarakat. Lingkungan sosial kultural dapat membentuk pribadi seseorang karena manusia berfikir dan ingin tahu serta mencoba-coba dari lingkungan yang tersedia. Lingkungan yang tersedia maksudnya adalah lingkungan rumah, sekolah, media elektronik (radio, televisi, internet dan telepon), media cetak (majalah, cerpen), teman dan sahabat, jalanan, pembantu dan 
tetangga. Menurut Muhaimin, lingkungan religius Islam dipengaruhi oleh sumber pandangan hidup Islam yaitu Al Qur'an sebagai Al-Wahy Al-Mathluu dan As-Sunnah sebagai Al-Wahy Ghoir Al-Mathluu (Muhaimain \& Mujid, 1993: 22).

Masyarakat religius Islam disebut Muslimin. Fungsi religi bagi masyarakat yaitu (1) sebagai etos yaitu dijadikan anutan jika diyakini dan dihayati secara mendalam memberikan tatanan nilai moral dalam sikap. (2) sebagai motivasi yaitu untuk mengejar tingkatan yang lebih baik (Jalaludin, 2008: 316).

Lalu bagaimana dengan Fitrah/Fisiologis dan Psikologis. Dimensi fitrah manusia terbagi menjadi tiga bagian: fitrah jismiah atau jasadiah, fitrah ruhaniah atau fitrah ilahiyah dan fitrah nafsaniah atau fitrah hayamaniyah. Ketiga fitrah ini memiliki natur, potensi, hukum dan ciri-ciri tersendiri (Mujib, 1999: .39)

Fitrah jismiah (Fisik) adalah citra penciptaan fisik manusia yang terdiri atas struktur organisme (Ibid: 40). Fitrah jismiah ini merupakan materi abiotik (tidak hidup) yang akan hidup apabila diberi energi kehidupan (al-hayat) yang bersifat fisik (thaqat al-jismiyat). Fitrah ini meliputi pertama, sistem reseptor seperti mata untuk melihat, telinga untuk mendengar, hidung untuk membau, kulit untuk meraba yang disebut dengan panca indra (sensorik). Kedua, sistem syaraf (nervous system) yaitu totalitas jaringan neural yang terdiri atas komponen-komponen sensorik dan motorik atau kedua-duanya. Sistem ini terdiri dari sistem syaraf sentral: terdiri atas otak dan urat syaraf tulang belakang, dan sistem syaraf peripheral: terdiri atas semua serat atau serabut syaraf yang menghubungkan reseptor dan efektor dengan sistem syaraf (Mujid, 1999: 47-48). Sistem syaraf ini berfungsi sebagai fungsi volunter (kemauan) dan fungsi kesadaran, perangsang, autonomic dan non-volunter. Kedua sistem di atas, akan berfungsi apabila dibantu oleh fungsi-fungsi sistem kelenjar (gland system). Sistem kelenjar adalah totalitas organ yang khusus mengeluarkan subtansi atau zat yang sangat diperlukan di dalam tubuh atau yang dikeluarkan oleh tubuh, yaitu endogtrin dan eksoktrin yang akan berfungsi dengan mengasumsi makanan dan minuman. Dalam pandangan Islam, asumsi makanan dan minuman yang halalan toyiban akan sangat berpengaruh pada sistem lainnya baik secara empirik maupun batiniah. Fitrah ini disebut juga fitrah hayawaniyat yang bersifat kemanusiaan (nasutiyat) (Ibn Qayyim al-Jauziyyah, 1992: 13).

Fitrah ruhaniah, (psikis) yaitu citra penciptaan psikis manusia yang mempunyai komponen, potensi, fungsi, sifat, prinsip kerja, dinamisme dan mekanisme tersendiri untuk mewujudkan hakekat manusia sebenarnya (Mujid, 1999: 49). Sifatnya tidak dibatasi oleh ruang dan waktu. Hadir sebelum jasad manusia ada. Setelah turun kepada natur jasad manusia menjadi nama al-nafs (Ibid: 49-53). Fitrah ruhaniah terdiri dari: pertama, fitrah almunazzalah yaitu potensi ruhani manusia yang diturunkan/diberikan langsung dari Allah tanpa daya dan pilihan, diciptakan di alam imateri ('alam al-arwah), melekat pada diri manusia dan sifatnya sangat gaib, diketahui hanya melalui informasi wahyu/ilham. Wujudnya berupa alamanah (titipan). Bentuk amanahnya berupa (1) kewajiban-kewajiban 
berupa menjalankan perintah dan menjauhi larangan; (2) hukumhukum yang wajib ditegakkan; (3) keyakinan menjalankan agama, tauhid, keadilan dan akal; (4) menemukan hukum alam dan menguasainya (Ibid: 53-54). Oleh karena itu, dalam perkembangannya fitrah munazzalah perlu pengingat, petunjuk dan pembimbing. Kedua, fitrah al-gharizat disebut juga fitrah nafsaniyah (daya insting/bawaan) yang berhubungan dengan fitrah jismiyah.

Fitrah nafsaniah yaitu citra penciptaan psikopisik merupakan gabungan komponen jasad dan ruh. Fungsinya memberi daya akal (Qowwah Al-Aql), meliputi AnNadhor (daya kognisi) dan Al-Irodah (emosi, daya menilai); memberi daya afensif (Qowwah As Syahwah) yaitu daya potensi untuk menginduksi diri dari segala yang menyenangkan dan berguna; memberi daya defensif (Qowwah Al-Ghodob) yaitu daya yang berpotensi untuk menghindarkan diri dari segala yang membahayakan (Muhaimin \& Mujib, 1993: 22, juga S. Praja, 1990: 75-76).

Apabila berorintaasi pada natur jasad maka prilaku menjadi buruk, apabila pada natur ruh maka kehidupan menjadi baik. Fitrah ini memiliki potensi gharizah (insting/bawaan) yang mendorong dan penentu tingkah laku manusia, baik perbuatan, sikap maupun ucapan. Sehingga mempunyai kemampuan untuk menerima stimulus dari luar dan berhubungan dengan kognisi (pengenalan/cipta=daya $a l$-aql), emosi (perasaan/rasa=daya al-qalb), dan konasi (kemauan/karsa=daya an$n a f s$ ).

Dalam pandangan Islam, daya akal yaitu suatu konsep umum yang mampu menangkap hal-hal yang rasional (masuk akal), menunjukan subtansi berfikir, berpendapat, memahami, menggambarkan, menghafal, menemukan, dan mengucapkan (Ma'an Zidayat, dkk, 1986: 596), dan merupakan daya nalar, atau daya argumentsi, disebut juga fitrah insaniyah (Mujid, 1999: 65). Daya kalbu disebut juga fitrah ilahiyah atau rabbaniyah karena merupakan esensi manusia yang mampu mengenal lingkungan spiritual, ketuhanan dan keagamaan. Sehingga mampu menangkap hal-hal yang doktrin untuk memperoleh hidayah, ketaqwaan, ramah, dan mampu merenungkan sesuatu (Ibid). Kalbu juga memiliki daya-daya emosi. Daya emosi dibangkitkan oleh motivasi yang menimbulkan interaktif. Sehingga muncul emosi positif dan negatif. Emosi positif seperti senang, gembira, percaya, tulus, cinta dan sebagainya. Emosi negatif seperti benci, sedih, dendam, selingkuh (munafiq), ingkar dan sebagainya. Emosi ini, dapat diaktualisasikan melalui rasa intelektual, rasa inderawi, rasa etika, rasa estetika, rasa sosial, rasa berekonomi, rasa religius dan lainlain (Zidayat, 1986: 59-64). Fungsi utama dari qalb adalah sebagai alat untuk memahami realitas dan nilainilai kehidupan dalam (tersirat Q.S surat al-Hajj: 46). Daya nafsu dalam pandangan Islam, adalah suatu daya yang mengikuti prinsip kenikmatan dan berusaha mengumbar keinginan agresif (al-ghadhab) dan seksual (assyahwat). Al-ghadhab disebut juga defense yaitu potensi diri dari segala yang membahayakan sehingga mampu mempertahankan, pembelaan dan penjagaan. Dengan kata lain, alghadhab adalah tingkah laku yang 
berusaha membela, melindungi ego terhadap kesalahan, kecemasan, rasa malu serta berusaha melindungi diri sendiri dan memanfaatkan serta merealisasikan perbuatannya sendiri (Al Ghazaliy, t.t: 348). Al-syahwat disebut juga appetite yaitu daya yang berpotensi untuk menginduksi diri dari segala yang menyenangkan, dan memiliki implus agresif. Oleh karena itu, nafsu memilki perpaduan ciri syahwat dan ghadhab yang menghasilkan tingkatan yang irasional yang disebut konasi dan ditandai dengan tingkah laku yang bertujuan untuk berbuat (C.P Caplin alih Bahasa Kartini Karono, 1989: 101).

Dengan demikian, fitrah terdiri dari fitrah jismiah sebagai alat penggerak (motorik) dan fitrah ruhaniah sebagai energi daya jismiah yang melahirkan fitrah nafsaniah. Fitrah nafsaniah inilah yang melahirkan aspek kognitif, afektif dan psikomotorik.

Kepribadian/al-syakhshiyat

diartikan sebagai kesan paling penting yang ditimbulkan individu terhadap orang lain. Para psikolog memandang kepribadian sebagai struktur dan proses psikologi yang tetap, yang menyusun pengalamaanpengalaman individu terhadap lingkungan tempat ia hidup. Kepribadian menurut Muhammad Utsman Najati mencakup sikap, sifat, watak dan temperamen, sehingga perlu diketahui motif atau niatnya. Kepribadian akan menentukan tabiat yang unik selaras dengan lingkungannya. Individu akan bertindak dan memberi respons sebagai kesatuan fisik dan psikis yang saling mempengaruhi dan menentukan perilaku dengan respons yang berbeda (Najati, 2005: 359).
Kepribadian manusia menurut Islam dikategorikan pada dua hal. Pertama, Kepribadian tanpa hidayah. Kepribadian ini berkembang tanpa atau belum mendapat hidayah melainkan mengikuti hawa nafsu. Kedua, Kepribadian yang mendapat hidayah Allah, yaitu kepribadian yang menjalankan syariat Islam, takwa, melaksanakan amal shaleh untuk kemajuan, kemakmuran dan kesejahteraan ummat manusia. Ibin Kutibin Tajudin menyebut kepribadian ini dengan sebutan Muslim, Insan Kamil, Akhlak Karimah, Nafsul Mutma'innah atau Qalbun Salim (Tajudin, 2007: 82). Berbicara tentang kepribadian, tidak lepas dari filosofis tentang manusia. Manusia adalah mahluk biobudaya, artinya sebagai mahluk hidup yang terdiri dari badan dan jiwa. Dalam badanya terdiri dari bermacam-macam sistem organ badan dan system saraf yang dikoordinasikan oleh saraf otak. Badan (fisik) dalam Studi Islam disebut Jism. Jism berkaitan dengan istilah biologi yaitu pertumbuhan (perkembangan fisik). Pertumbuhannya akan mempengaruhi psikis, contoh berkembangnya fungsi organ tubuh dengan baik memungkinkan orang hidup optimis. Pertumbuhan fungsi otak memungkinkan seseorang mampu berfikir. Bertambahnya fungsi otak seseorang memungkinkan bisa bicara, berjalan, berekspresi dan bertingkah laku lainnya. Jiwa (psikis) dalam studi Islam disebut nafs. Nafs terwujud dari dampak kondisi qalb dan jism. Jika qalb dan jism-nya rusak akan berdampak pada nafs yang rusak. Nafs diwujudkan dalam prilaku. Maka bila nafs-nya rusak akan 
terakulturasi muncul gejala prilaku yang rusak. Nafs berkaitan dengan istilah psikologi yaitu perkembangan.

Manusia yang baik dalam pandangan Islam mengarahkan perjalanan hidupnya kearah kebaikan (as-shirath al-mustaqim ila al-haq). Rafy mengatakan bahwa pengembangan kepribadian yang Islami adalah usaha setiap individu dengan kekhasan daya insaninya yang menempuh perjalanan hidup secara fisik dan psikis kearah kebenaran. Dalam hal ini menurutnya ada tiga unsur keterkaitan terpadu (centered relationship) meliputi kekhasan daya insani, perjalanan hidup dan kebenaran (Rafi Safuri, 2009: 109).

Rafy memberi statemen bahwa langkah pengembangan kepribadian Islami yang harus diperhatikan pertama adalah pengembangan qalb. Dalam hal ini qalb diistilahkan dengan hati. Qalb atau hati adalah tempat bermuara segala kebaikan Ilahiah, karena ruh ada di dalamnya. Kedua, adalah jism (fisik) karena fisik dengan seluruh anggota badannya dapat dilihat, diraba dan memiliki panca indra sebagai alat pelengkap (Ibid: 113).

Paparan di atas, hal yang perlu diperhatikan dalam menerapkan teori belajar sosial adalah peningkatan motivasi. Dalam psikologi sosial Barat, termasuk teori social learning dalam membentuk motivasi menekankan pada garis fisik, biologis, dan kognitif semata. Sedangkan dalam pandangan psikologi Islam, selain peningkatan motivasi juga menekankan landasan spiritual, sehingga dalam membentuk motivasi pun harus berdiri di atas spiritual Islami (Ibid: 224). Motivasi yang dimaksud adalah amanah yang telah diberikan pada alam pra- kehidupan di dunia untuk dipertanggungjawabkan di akhirat (Mujid, 2001: 247).

Jadi hal yang perlu diperkenalkan dalam belajar sosial selain memperkenalkan lingkungan sosial yang terikat oleh norma dan agama, juga perlu diperkenalkan pluralisme agama dan motivasi spiritual agama, dalam artian mental perlu diperhatikan.

Masa depan suatu masyarakat bangsa atau negara akan tergantung pada cita-cita dan ide atau kehendak dari suatu masyarakat itu sendiri. Cita-cita yang mengarah ke masa depan akan menstimuli pada suatu aktivitas yang divisualisasikan melalui keberadaan mentalnya. Keberadaan mental ini merujuk pada aspek intelektual dan dorongan pada suatu tujuan (Al Shadr, 1993: 123). Tujuan inilah yang akan mempengaruhi kinerja seseorang. Ketika seseorang telah membuat tujuan, ia akan mengarahkan dan mengembangkan rencana untuk bertindak mencapai tujuan melalui keyakinan bahwa ia dapat tampil memadai untuk berusaha mampu menggapai menuju pencapaian tujuan.

Berbicara tentang kinerja yang berkualitas, diperlukan perpaduan pendidikan nalar dengan pendidikan agama tentang keduniaan dan univers (kauniyah) (Djatnika, 1996: 2-4). Kenyataan fenomena menurut Rachmat Djatnika, bahwa kehidupan agama masih menjadi kendala. Pertama, keimanan dalam memeluk agama belum kuat. Kedua, masih banyak orang yang belum tersentuh peningkatan pendidikan keimanan dengan pendidikan nalar. Ketiga, belajar agama masih banyak dirasakan berat, mutunya kurang dan terjadi apa adanya (Djatnika, Ibid; 6). 
Hal ini tercermin dari pola prilaku dan kinerja yang tidak kondusif dan bersifat individualistis. Ditambah dengan adanya Informasition Communication Technology yang beredar lebih mudah merangsang rasa ingin tahu, rasa ingin mencoba dan lebih cepat diserap daripada membaca dan mendengarkan.

Sementara dalam hal ini, Islam mempunyai peranan besar dalam pendidikan moral, tetapi dalam menghadapi perluasan kesempatan belajar sosial, masih adanya ketidakseimbangan pertumbuhan masyarakat dan perikehidupan sebagai implikasi dari globalisasi, sains dan teknologi (Supardi, Ibid: 11-13).

Islam sebagai agama adalah suatu ciri kehidupan sosial manusia yang universal dalam arti bahwa semua masyarakat mempunyai caracara berpikir dan pola-pola prilaku yang memenuhi syarat untuk disebut “agama' (religious). Terdapat banyak tema agama termasuk dalam superstruktur: agama terdiri atas tipetipe simbol, citra, kepercayaan dan nilai-nilai spesifik yang menggambarkan manusia menginterpretasikan eksistensinya sebagai makhluk. Tetapi karena agama Islam mengandung komponen ritual, proses penilaian dan sistem maka sebagai agama Islam tergolong dalam struktur sosial.

Keterkaitan antara norma dengan struktur sosial berfungsi sebagai ketentuan dan petunjuk pelaksanaan proses penilaian dan sistem norma manusia sebagai pelaku budaya dan sebagai prasarana bagi pola prilaku dan akhlak manusia. Cermin kualitas kinerja dari hasil belajar sosial terwujud dalam fenomena-fenomena sosial dalam segi aktivitas kerja, budaya kerja dan etos kerja.

\section{Implikasi Belajar Sosial Islam Terhadap Sosial Budaya}

\section{Dalam}

teori-teori

kebudayaan, Sulasman bependapat bahwa tsaqafah (pandangan hidup) dimaknai sebagai suatu konsep pemikiran dan pandangan hidup yang telah membentuk pola pikir dan prilaku suatu masyarakat dan merupakan bagian yang tidak terpisahkan dari hadharah (persepsi) yang nantinya akan menjadi mafahim (pemahaman) yang mengantarkan pada terciptanya pada suatu peradaban (Sulasman, 2013: 22). Rafi Sapuri menjelaskan bahwa kata adab dalam Islam diistilahkan sebagai ijtimâ'u khishâl al-khair fi al 'a Rasulbdi (berkumpulnya perangai yang baik pada seorang hamba) (Safuri, 2009: 72).

Dalam pandangan Islam, adab terbagi dalam tiga bagian: (1) adab kepada Alloh, (2) adab kepada rasul dan (3) adab kepada makhluk. Artinya bahwa adab adalah agama secara keseluruhan. Dalam Islam, adab identik dengan ketaatan kepada Alloh dan rasul-Nya yang digambarkan sebagai nilai tertinggi dari segala aktivitas manusia yang istiqomah dalam rangka mendapatkan kebahagiaan yang hakiki. Pencapaian kebahagiaan hakiki ini tidaklah mudah didapatkan melainkan akan mendapatkan banyak tantangan. Tantangan tersebut bisa dari dirinya sendiri bisa berupa hawa nafsu, nafsu amarah, atau kekurangan-kekurangan yang ada pada diri manusia itu sendiri maupun di luar dirinya sendiri yaitu tipu daya syetan.

$\begin{array}{ccc}\text { Mahfudin } & \text { Noor mengatakan } \\ \text { bahwa } & \text { Islam adalah agama }\end{array}$


transcendental yang bersumber dari Ilahi, diciptakan untuk menciptakan manusia sebagai bagian dari kebudayaan, karena Islam merupakan sumber kekuatan yang mendorong munculnya suatu kebudayaan (Noor, 2002: 81). Ia juga menambahkan bahwa Islam selain mengatur segi-segi ritual juga mengandung ajaran-ajaran yang dapat dijadikan asas-asas kebudayaan. Intinya bahwa Islam mengandung ruh intiqat yaitu suatu kekuatan yang dapat menyiasati dan menyelidiki kebenaran (Ibid: 82).

Sementara itu, tantangan yang dihadapi umat Islam saat ini adalah revolusi IPTEK yang membawa ketergantungan kehidupan di segala bidang pada ICT (Information Communication Tecnology) terutama pada bidang perekonomian, termasukdi dalamnya MEA. Revolusi ini akan berdampak pada perubahan-perubahan dasar sikap dan tingkah laku baik orang, kognisi dan lingkungan yang melahirkan gaya baru dalam kehidupan berkeluarga, cara dan etos kerja, politik dan sosial budaya dalam kesadaran mental baru. Bila umat Islam mampu menghadapi dan menjawab tantangan terhadap problematika tersebut melalui nilainilai agamanya, maka akan menjadi sangat bermakna bagi permasalahan sosial dan budaya pada seluruh umat manusia di dunia ini.

Fasalnya, Islam dengan landasan ajaran spiritual, etika dan moral yang khas atas dasar ajaran wahyu dan suri tauladan yang dibuktikan dengan keimanan dan taqwaan yang mantap serta berkewajiban pada keseimbangan, keserasian dan keselarasan dunia dan akhirat secara terpadu akan mampu menjadi inspirasi dan merangsang semangat nilai-nilai agama yang sangat bermakna dalam menguasai dan mengembangkan serta memanfaatkan IPTEK bagi seluruh dunia. Umat Islam dengan penuh kejujuran harus mampu bekerja keras meningkatkan civilitasi ilmu pengetahuan, mutu pendidikan dan penguasaan IPTEK melalui ketegaran kepribadian dan kemantapan rohani yang tersimpul dalam kecerdasan dan kemantapan mental spiritual yang tercermin dalam kepribadian yang berkualitas.

Dengan demikian, umat Islam dengan nilai-nilai Islaminya harus mampu berbudaya modern yang maju melalui interaksi sosial yang sehat sehingga dapat memperkuat bahtera peradaban dunia baru yang menguasai IPTEK, modern, maju, kuat mental dan mantap spiritualnya.

Disini peran Islam adalah memberi kontribusi dalam memproyeksikan masa depan kehidupan bermasyarakat yang berbudaya, berwatak dengan cara hikmah dan damai guna terciptanya kemaslahatan dunia (rahmatan lil'alamin).

Islam $\begin{array}{r}\text { Esensinya, } \\ \text { dalam }\end{array} \quad \begin{array}{r}\text { prospek umat } \\ \text { memecahkan }\end{array}$ permasalahan sosial budaya yang modern, maju, beretika, bermoral dan berestetika tergantung pada keberhasilan umat Islam itu sendiri baik secara individu maupun masyarakat dalam memanifestasikan kecerdasan dan kemantapan rohani dalam mentauhidkan-Nya yang diimplementasikan dalam kepribadian untuk diimplikasikan pada prilaku.

Ekspresinya, ijtihad sebagai dinamika dan peradaban Islam dipandang penting dalam mewujudkan pemecahan persoalan sosial budaya masa kini. Hal itu 
menuntut para mujtahid bekerja keras dan bersungguh-sungguh menggali ilmu pengetahuan secara umum dan mengajarkan Islam dengan sebenar-benarnya, disebabkan karena:

1. Dimungkinkan nash-nash assunnah sebagai sumber pedoman hidup ke dua setelah Al Qur'an banyak terlupakan sehingga terjadi perubahan nash karena terjadinya asimilasi dan akulturasi budaya.

2. Kebudayaan bersifat dinamik sehingga cara hidup manusia beserta amalannya mengalami perubahan kesan yang merubah prilaku dan falsafah masa.

3. Perubahan prilaku tersebut akan meregenerasi menjadi suatu tradisi yang berkesinambungan dan melahirkan kreativitas yang bertolak belakang dengan nashnash Al Qur'an sebagai tonggak filosofi hidup dan kehidupan manusia.

Oleh karena itu, studi Islam dengan berbagai dinamika keilmuannya perlu melirik keilmuan lainnya untuk dipertimbangkan dan diarahkan kepada keimanan dan ketaatan pada syar'i serta pembentukan mental yang mampu menegakkan tauhidulloh sebagai penghambaan dirinya pada Tuhannya.

\section{Kesimpulan}

Keterkaitan antara norma dengan struktur sosial berfungsi sebagai ketentuan dan petunjuk pelaksanaan proses penilaian dan sistem norma manusia sebagai pelaku budaya dan sebagai prasarana bagi pola prilaku dan akhlak manusia. Cermin kualitas kinerja dari hasil belajar sosial terwujud dalam fenomena-fenomena sosial dalam segi aktivitas kerja, budaya kerja dan etos kerja.

Oleh karena itu, studi Islam dengan berbagai dinamika keilmuannya perlu melirik keilmuan lainnya untuk dipertimbangkan dan diarahkan kepada keimanan dan ketaatan pada syar'i serta pembentukan mental yang mampu menegakkan tauhidulloh sebagai penghambaan dirinya pada Tuhannya.

Implikasi belajar sosial dalam perspektif Islam terhadap sosial budaya harus mencerminkan ciri-ciri yang bernafaskan tauhid dan hasil pembelajaranya harus mencerminkan peningkatan spirit sumber ajaran Islam yaitu Al Qur'an dan as-Sunnah yang dilakukan oleh seluruh ummat Islam atas dasar dedikasi kepentingan dan kemaslahatan ummat.

\section{DAFTAR PUSTAKA}

Albert Bandura, (1969), The Role of Modeling Processes In Personality Development, (Ed) Donna M. Gelfand in Social Learning in Childhood, California: A Division of Wadsworth Publishing Company, Inc.

$$
\text { (1977), Social }
$$

Learning Theory, Engliwood Cliffs, NJ: Pretice Hall.

(1986), Social foundations of thought and action: A social cognitive theory, Perntice Hall: Engliwood Cliffs.

\section{(1999), Social}

Cognitive Theory:A Agentic Persfektive, Asian Journal of Social Psychology, USA:Stanford Universiity. 


\section{(1996), Social $\begin{array}{ll}\text { Learning Theory, New } & \text { Nersey: Prentice-Hall, } \\ \text { INC, }\end{array}$ Engliwood Cliffs. \\ (1980), Social \\ Cognitif Theory, In R. Vasta \\ (Ed), Annals of child development. Vol. 6. Six theories of child development (pp. 1-60) (Greenwich: CT: JAI Press. \\ Negative self-efficacy and goal effects revisited, Journal of Applied Sychology.}

Ali Syaria'ati, (1982), Sosiologi Islam, Yogyakarta: Ananda..

Al Ghazali, (t.t), Ihya' 'Ulum AdDin, Jilid III, Mesir: Dar AlIhya wa Al Kutub AlArabiyah.

Asy-syati, (1966), Al Maqal fi alInsan: Dirasah Qur'aniyah, Mesir: Dar al-Ma'arif.

Abu Ahmadi, (2007), Psikologi Sosial, Jakarta: Rineka Cipta.

Asep Ahmad Hidayat, (2003), Perubahan Sosial dalam AlQur'an, Dialektika Budaya Vol. XI No.1/2003, Bandung: Fak. Adab IAIN SGD.

(2006), Filsafat

Bahasa: Mengungkap Halikat

Bahasa, Makna dan Tanda, Bandung: Remaja Rosdakarya.

Abdul Mujib, (1999), Fitrah \& Kepribadian Islam Sebuah Pendekatan Psikologis, Jakarta: Darul Falah.

Abdul Mujid, Jusuf Mudzakkir, (2008), Ilmu Pendidikan Islam, Jakarta: Prenada Media Group, 2008.

$\begin{array}{rlr}\text { nuansa } & \text { Psikologi Islam, }\end{array}$

Jakarta: Raja Prasindo Persada.

Ayams al-Din ibn 'Abd Allah Ibn Qayyim al-Jauziyyah, (1992), al-Ruh, Beirut: Dar al-Fikr.

Abu Hamid Muhammad al-Ghazaliy, (t.t), Maqashid al-Falasifat, editor Sulaaiman Dunya, Mesir: Dar al-Ma'arif.

Ahmad Tafsir, (2006), Filsafat Pendidikan Islam, Bandung: PT Remaja Rosdakarya.

--------------, (2008), Ilmu

Pendidikan Dalam Perspektif Islam, Bandung: Remaja Rosdakarya.

Ahmas Supardi, (1996), Pendidikan Agama: Mengatasi Transisi Budaya. Mimbar Studi no. 76/xvii/januari/1996, Bandung: IAIN SGD.

B.R. Hergenhahn \& Matthew H. Olson, (2008), Theories of Learning, alih bahasa oleh Tri Wibowo B.S, Jakarta: Prenada Media Group Kencana.

Badruddin Muhammad, (2010), Manusia dalam Perspektif Al Qur'an, tersedia: badruddinmuhammad. Blogspo .com/.../manusiadalam-prespektif-alquran.html -

C.P Caplin, (1989), Kamus Lengkap Psikologi, terj. Kartini Kartono, Jakarta: Rajawali.

C. George Boeree, (17 April 2010) tersedia:http://webspace.ship. edu/cgboer/bandura.

htmlAlbert Bandura.

Gerungan, WA, (2004), Psycologi Sosial, Jakarta: Felika Aditama. $\begin{array}{llr}\text { (2004), } & \text { Bsikologi } & \text { Sosial } \\ \text { Aditamand } & \end{array}$

Goegle. Httpw///Strickland. 2001 
(2009), Tersedia:

http://fisikaumm.blogspot.co

$\underline{\mathrm{m} / 2009 / 01 / \text { teori-belajar }}$

menurut-islam.html

Gibson, Ivancevich, Donnelly, (1996), Organisasi, alih bahasa Nunuk Adiarni, Jakarta: Binarupa Aksara.

Harun Nasution (1986), Akal dan Wahyu dalam Islam, Jakarta: UI Press.

Ibin Kutibin Tadjudin, (2007), Psikoterapi Holistik Islami, Bandung: Kutibin.

John W. Santrock, Educational Psychology, alih bahasa Tri Wibowo B.S edisi 2, cet. 2 (Jakarta; Prenada Media Group), .

Jalaluddin Al-Mahalli, JalaluddinAsSyuyuthi, (1997), Tafsir Jalalain Berikut Asbaabun Nuzuul Ayat, Jilid I-IV, Bandung: Sinar Baru Algensindo.

Jalaludin, (2009), Psikologi Agama, edisi revisi, Jakarta: Raja Grafindo Persada.

Juhaya S. Praja, (1990), Ulumul Qur'an, no. XII, II/1990, Bandung: UIN SGD.

Jurnal Mimbar Studi No. 3 Tahun XXII, Mei-Agustus 1999, Bandung: Mimbar Studi.

Muhibin Syah, (1995), Psikologi Pendidikan Suatu Pendekatan Baru, Bandung: PT Remaja Rosdakarya.

9, Psikologi Belajar, Jakarta: PT Raja Grafindo Persada.

Pendidikan dengan

Pendekatan Baru, (Bandung: PT Remaja Rosda Karya.

Muhaimin \& Abd. Mujib, (1993), Pemikiran Pendidikan Islam, Bandung: Trigenda Karya.
Muhaimin, (2002), Paradigma Pendidikan Islam, (Bandung: PT Remaja Rosdakarya.

Mudlor Ahmad, (t.t), Manusia dan Kebenaran, Surabaya: Usaha Nasional.

---------------, (1997) Pengantar Ilmu Jiwa Umum, Yogyakarta: Andi.

Muhammad Utsman Najati,(2005), Psikologi dalam Al Qur'an, alih bahasa M. Zaka Alfarisi, Bandung: Pustaka Setia,.

Ma'an Zidayat, dkk, (1986), alMausu' al-Falsafiyah al'Arabiyat, Arab: Inma' al'Arabiy.

Muhammad Nasib ar-Rifa'i, (2004), Taisiru al-Aliyyul Qadir li Ikhtishari Tafsir Ibnu Katsir, jilid 3, penerjemah Syihabudin, Jakarta: Gema Insani.

Mujid, Jusuf Mudzakkir, (2008), Ilmu Pendidikan Islam, (Jakarta: Prenada Media Group.

Musa Asy'ari, (1992), Manusia Pembentuk Kebudayaan dalam Al Qur'an, cet I Yogyakarta: Lembaga Studi Filsafat Islam.

Nur Ahid, (2010), Pendidikan Keluarga dalam Perspektif Islam, Yogyakarta: Pustaka Pelajar.

Nurwadjah Ahmad, (2007), Tafsir Ayat-ayat Pendidikan: Hati yang selamat hingga kisah Luqman, Bandung: Marja.

Robert E. Slavin, (1986), Educational Psychology Theory into Practice, New Jersey: Prentice Hall, Engliwood Cliffs.

Robert A Baron, Donn Byrne, (2004), Psikologi Sosial, Jilid I edisi 10, alih bahasa 
Ratna Djuwita, Jakarta: Erlangga.

Ramdhan Muhammad Qadzafi, (1990), Ilmu An Nafsi Al Islami, Jamahiri: Shihifata Ad Da'awati Al Islamiyah.

Rachmat Djatnika, (1996), Normanorma Agama dalam Realitas Sosial di Indonesia, Mimbar Studi no. 76/xvii/januari/1996, Bandung: IAIN SGD.

Rafy Sapuri,(2009), Psikologi Islam: Tuntunan Jiwa Manusia Modern, Jakarta: Rajawali Pers.

Rizza Aria Ferdian, (t.t), tersedia: http://rizza-afguruindo.blogspot.com/2010/ 07/ mengembangkanketerampilan-sosialpada.html. (Senin, 12 Juli 2010)

Sofyan Anwar Mufid, (2010), Islam \& Ekologi Manusia: Paradigma Baru, Komitmen dan Integritas Manusia dalam Ekosistemnya, Refleksi Jawaban atas Syahminan Zaini, Muhaimin, (1991), Belajar sebagai Sarana Pengembangan Fitrah Manusia, Jilid 1, Jakarta: Kalam Mulia.

Wikipedia, (t.t), tersedia: http://en.wikipedia.org/wiki/ Albert_Bandura.

--------, (t.t), tersedia: http//www.emory.edu/EDUC ATION/mfp/bandurabio .html [17April 2010]

------, (t.t), Pendidikan dan Basis Akademik, Tersedia: Error! Hyperlink reference not valid.. (17 April 2010). 